\title{
ECONOMIC ANALYSIS OF SOILLESS AND SOIL-BASED GREENHOUSE CUCUMBER PRODUCTION IN TURKEY
}

\author{
Sait Engindeniz ${ }^{1 *}$; Ayse Gül ${ }^{2}$ \\ ${ }_{2}^{1}$ Ege University/Faculty of Agriculture - Dept. of Agricultural Economics - 35100 Bornova, Izmir - Turkey. \\ ${ }^{2}$ Ege University/ Faculty of Agriculture - Dept. of Horticulture. \\ *Corresponding author <sait.engindeniz@ege.edu.tr>
}

\begin{abstract}
Since the onset of the commercial application of soilless culture, this production approach has evoluted at a fast pace, gaining popularity among growers throughout the world. As a result, a lot of information has been developed by growers, advisors, researchers, and suppliers of equipment and substrate. This study aimed to determine the cost and return of soilless greenhouse cucumber (Cucumis sativus L.) production and to prepare a sample budget for growers. Soilless cultivation is an alternative production method for Turkish growers and it is being practised on a commercial basis on 180 ha. Cost and return budgets can be useful for growers because they allows growers to compare total production cost and revenue varying grower type, production time, geographical location, operation size, and cost structure. Growers can identify items in their budget that have a greater effect on profitability, and make adjustments. In this study, economic aspects of soilless and soil-based greenhouse cucumber production was analysed as comparative. Total costs were subtracted from total gross revenue to calculate the net return of soilless and soil-based greenhouse cucumber production. The cost items of soilless and soil-based greenhouse cucumber production were initial investment costs, variable costs, and fixed costs. Net return obtained from cucumbers grown in a mixture of perlite and zeolite was determined as $€ 1.84 \mathrm{~m}^{-2}$, whereas it was $€ 1.48 \mathrm{~m}^{-2}$ in conventional soil-based production. Production and market risks both affect profitability and economic viability of soilless grown vegetables.

Key words: Cucumis sativus L., vegetable, alternative agriculture, closed system, economic feasibility
\end{abstract}

\section{ESTUDO ECONÔMICO DAPRODUÇÃO DE PEPINO EM CULTIVOS COM E SEM SOLO EM CASAS DE VEGETAÇÃO NATURQUIA}

\begin{abstract}
RESUMO: Desde o início da implantação de cultivos comerciais sem solo suas técnicas de produção tem evoluido em ritmo acelerado, ganhando popularidade entre agricultores de todo o mundo. Como resultado, uma grande quantidade de informação tem sido desenvolvida pelos produtores, consultores, pesquisadores e fornecedores de equipamentos e substratos. Determinaram-se o custo e retorno financeiro da produção de pepino (Cucumis sativus L.) e preparou-se um exemplo de orçamento para produtores. Na Turquia o cultivo sem solo é um método alternativo de produção para agricultores e é praticado em bases comerciais em 180 hectares. Por conseguinte, avaliações de custos e retornos podem ser úteis para produtores porque permitem aos mesmos comparar o custo total da produção e o retorno segundo variações de tipo de olericultor, tempo de produção, localização geográfica, tamanho do empreendimento e custo das estruturas. Os produtores podem assim identificar quais itens em seus orçamantos tem maior efeito na rentabilidade e fazer ajustes. Nesse estudo aspectos econômicos de cultivos de pepino em casas de vegetação sem solo e com solo foram analisados e comparados.Os custos totais foram subtraidos das receitas brutas para fins de cálculo do retorno líquido de produções de pepino em cultivos com e sem solo. Os custos dos itens dos cultivos com e sem solo foram: investimentos iniciais, custos variáveis e custos fixos. O retorno líquido obtido pelos produtores de pepino cultivados em um substrato de perlita e zeolita foi de $€ 1.84 \mathrm{~m}^{-2}$ e de $€ 1.48 \mathrm{~m}^{-2}$ para o cultivo convencional com solo. Contudo, riscos de produção e de mercado afetam a rentabilidade e viabilidade econômica de hortaliças cultivadas sem solo.

Palavras chaves: Cucumis sativus L., hortaliças, agricultura alternativa, sistemas fechados, viabilidade econômica
\end{abstract}

\section{INTRODUCTION}

Since the announcement that methyl bromide would be phased out due to its role as an ozone depleter, growers must identify technical and economically feasible alternative production methods as a replacement for methyl bromide. Hydroponics or soilless cultures can be viable alternative to methyl bro- 
mide soil fumigation for tomatoes, strawberries, cucumbers, peppers, eggplants, and some flowers (Tognoni \& Pardossi, 1998; Burrage, 1999; Os, 2000). There are two main types of soilless cultivation, which are called as open and closed systems. Closed systems in which nutrient solution is recirculated provide economy in water and nutrient use and reduce environmental pollution. Closed system could be used for production of different crops without yield and quality loss (Os, et al., 1991; Vernooij, 1992; Willumsen, 1995; Böhme, 1996; Gül et al., 1999). A closed system may reduce water and nutrient consumption by 22 and 35\%, respectively, in cucumber production (Tüzel et al., 1999). Gül et al. (2001) report that volume of waste nutrient solution was four times higher in an open system $\left(2654.8 \mathrm{~m}^{3}\right.$ $\mathrm{ha}^{-1}$ ) compared to a closed system $\left(636.8 \mathrm{~m}^{3} \mathrm{ha}^{-1}\right)$ in tomato production.

In Turkey, studies on soilless culture have gained speed towards the end of 1980's. In the 1990's big companies have started to use soilless culture techniques via technology transfer from abroad. It is estimated that soilless culture is being practiced on a commercial basis only on 180 ha. This area is too small compared to total greenhouse area being more than 34,891 ha (Tüzel et al., 2008). In recent years, many studies have been made on soilless cucumber production in greenhouses in Turkey (Özgür, 1991; Canatar, 1997; Saracoglu, 1997; Öztan, 2002; Kaptan, 2006; Gül et al., 2006; Gül et al., 2007). Though, there is still need for study, especially on economics of soilless cucumber production at farmers' level.

The purposes of this study were to determine cost and returns associated with soilless greenhouse cucumber production in Menderes-Izmir and to develop a guide budget for small growers who intend to use soilless culture technique. Further, economic aspects of soilless and soil-based greenhouse cucumber production was analysed as comparative in this study.

\section{MATERIALAND METHODS}

\section{Greenhouse and soilless culture systems}

This study was realized in a polyethylene covered greenhouse $\left(384 \mathrm{~m}^{2}\right)$ built on the farmer's land located in Menderes that has been the most important place in Turkey in respect to cucumber production. Menderes is situated in the western part of Turkey between $38^{\circ} 15^{\prime} \mathrm{N}$ and $27^{\circ}$ and $28^{\circ} 30^{\prime}$ E. It has Mediterranean climate. The average annual temperatures, those of the warmest (July) and those of the coldest month (January) are rather similar for the entire river basin. The annual precipitation is about $550 \mathrm{~mm}$ and the average relative humidity is $63 \%$.
The project greenhouse as a sample for the region was not equipped with climate controllers similar to growers' conditions, sprinklers were put on the roof for frost protection and natural ventilation was done to change the temperature etc.

Substrate culture was used as a soilless technique and a closed system, which is considered as one of the alternative production method in sustainable agriculture, was applied in this study. The growing medium was a mixture of perlite and clinoptilolite (3:1, $\mathrm{v} / \mathrm{v})$. Horizontal plastic pots, which are available on the market, were used. At the preparation stage, the greenhouse floor was graded and compacted to give a uniform slope of about $1 \%$. After covering the surface with polyethylene sheet, pots were placed as double rows and two plants were grown in each pot. The substrate volume was $8 \mathrm{~L}$ per plant.

Nutrient solution, which is prepared according to Papadopoulos (1994), was applied via drip irrigation system by using a pump. The average ratio of drain water compared to applied volume was $38 \%$. EC (Electrical Conductivity) and $\mathrm{pH}$ of nutrient solution were checked by using portable $\mathrm{pH}$ meter and EC meter. Additions of stock solutions and acids to the mixture of drainage solution and fresh water were made manually according to $\mathrm{EC}$ and $\mathrm{pH}$ values.

\section{Plant production}

Since the main greenhouse crop in the region is cucumber, it was chosen as the plant material. The tested cultivar was Sardes being very common for commercial production. It has less vigorous plant growth and multi fruits per node. Plant production was realized parallel to growers' applications. Transplants were purchased from a commercial company and transferred into the greenhouse on March 17, 2001. Planting density was 2.666 plants per $\mathrm{m}^{2}$. Harvests started on April 30, 2001 and continued until August 10, 2001. The harvests were done every other day.

\section{Economic analysis}

Data related to yield and observations were recorded throughout the production period. Thus, income and expense data were collected in time and a budget for growers was developed. All technical and economic analysis of this research to prepare a sample budget for growers were based on an average greenhouse size $\left(1000 \mathrm{~m}^{2}\right)$. The cost items of greenhouse crop production can be classified into; initial investment costs, variable costs, and fixed costs (AlAbdulkador, 1992; Hood \& Snyder, 1999; Engindeniz \& Tüzel, 2002). The variable costs associated with crop production were all inputs that directly related to the production of cucumber and covered labor, fertilizers, seedling, electricity, marketing, transport, etc. 
costs. Variable costs were calculated by using current input prices and labor costs.

Fixed costs included interest on total initial investment costs, annual initial investment costs, interest on total variable costs, administrative costs, and land rent in this study. Interest is defined as a sum paid or calculated for the use of capital. The sum is usually expressed in terms of a rate or percentage of the capital involved, called the interest rate (Chaudhary, 2001). In this study, interest on total initial investment costs and total variable costs was calculated by charging a simple interest rate of $12 \%$ (annual saving deposits interest rates on $€$ ) on one-half of total initial investment costs and total variable costs. The reason to divide the annual interest by two is because the growers prefer to grow two crops yearly in unheated-greenhouses in this region (Hickman \& Klonsky, 1993; Estes \& Peet, 1999).

Administrative costs can be estimated to be $2-7 \%$ of total gross production value or 3-7\% of total costs (Mülayim, 2001; Kiral et al., 1999). In this study, administrative costs were estimated to be $3 \%$ of total variable costs. This method was applied in most of the previous studies (Engindeniz \& Tüzel, 2002; Engindeniz, 2004; Tüzel et al., 2005; Engindeniz \& Tüzel, 2006; Engindeniz \& Engindeniz, 2006). Depreciation for initial investment was estimated using the straight-line method (Penson et al., 2002; Lazol, 2007). Assets were divided by their useful life expectancies to determine annual costs for depreciation. For example, useful life for a galvanized frame and kit, polyethylene covering material, water pump, roof sprinkler, drainage tank were estimated to be 20, 2, 15, 20, and 20 years, respectively. It was also assumed rent equivalent of greenhouse area as land rent. For this aim, some information was obtained from land owners and people dealing with purchase-and-sales of lands in Menderes and it was determined to be $€ 162$. But, land rent was divided into two because most farmers grow two crops per annum in the region. In fact, land rent can be highly variable and depends on the location of the parcel. Additional factors like soil types and availability of water affect the rent of the land.

Greenhouse was exempted from property tax and was not insured. Fixed costs plus variable costs equaled to total production costs. Total costs were subtracted from total gross revenue to calculate the net revenue. However, the cost, yield, and price data were analyzed to determine the profitability of a typical soil-based cucumber production in this study. Twenty growers using the random sampling method from Menderes responded to an intensive survey designed to analyze these factors. Data was statistically analyzed and converted to an economic profile of a typical greenhouse module. A greenhouse structure of $1,000 \mathrm{~m}^{2}$ was selected as representing the most common economic module in terms of unit size most often used to expand an existing operation or used by potential entrants as a planning unit for entry into the greenhouse vegetable industry.

\section{RESULTS AND DISCUSSION}

Total yield was determined as $31,263 \mathrm{~kg}$ for 1,000 $\mathrm{m}^{2}\left(31.26 \mathrm{~kg} \mathrm{~m}^{-2}\right)$ in the experimental soilless cultivation in this study (Table 1). However, in other studies done under growers' conditions in Menderes, it was determined that yield obtained from the cucumbers grown in volcanic tuff placed in polyethylene beds by soilless culture were $24.53 \mathrm{~kg} \mathrm{~m}^{-2}$ (Engindeniz, 2004) changed beetween $15.07 \mathrm{~kg} \mathrm{~m}^{-2}$ and $32.65 \mathrm{~kg} \mathrm{~m}^{-2}$ (Gül et al., 2006). Yield depends on the cultivars and environmental conditions. In San Joaquin Valley, USA, a yield of $32.95 \mathrm{~kg} \mathrm{~m}^{-2}$ was obtained from cucumber plants grown by bag culture in a $1,860 \mathrm{~m}^{2}$ greenhouse (Hickman \& Klonsky, 1993).

In this study, itemized expenses associated with the production of cucumbers are given in Tables 2, 3, and 4. Table 2 explains costs for construction of the greenhouse. Initial investment costs were determined as $€$ 17,911 for a $1,000 \mathrm{~m}^{2}$ greenhouse $\left(€ 17.91 \mathrm{~m}^{-2}\right)$. Galvanized frame and kit, base locking rail and assembly and installation costs cover $61.8 \%$ of total initial investment costs. Annual initial investment costs were calculated as $€ 1,668$, and since most farmers grow two crops per annum in the region, the cost was divided into two. Thus, annual initial investment costs were estimated as $€ 834$ for cucumber production in spring season. Total and annual investment costs may change according to greenhouse type and size, climate control equipments and soilless culture technique used. Multiple greenhouses would increase the total expenditure but most likely they would reduce the cost per square meter because economic gains would be realized, the large production would reduce the cost of production per unit.

Production cost of the crop in a greenhouse is higher than producing it in the field. In estimating the construction cost of a new greenhouse, different factors like greenhouse frame and cover, climate control systems and plant growing systems may be included. It is reported that a commercial greenhouse $\left(279 \mathrm{~m}^{2}\right)$ with complete heating, cooling, and ventilation systems

Table 1 - Total yields obtained from soilless cucumbers.

\begin{tabular}{|c|c|c|c|}
\hline Total yield & Yield & $\begin{array}{l}\text { Yield per } \\
\text { plant }\end{array}$ & $\begin{array}{l}\text { Yield per plastic } \\
\text { pots }\end{array}$ \\
\hline $\mathrm{kg} 1000 \mathrm{~m}^{-2}$ & $\mathrm{~kg} \mathrm{~m}^{-2}$ & -....... & - \\
\hline 31,263 & 31.26 & 11.63 & 23.26 \\
\hline
\end{tabular}


Table 2 - Initial investment costs for greenhouse construction $\left(1,000 \mathrm{~m}^{2}\right)$.

\begin{tabular}{|c|c|c|c|c|c|}
\hline Item & Initial Cost $(€)$ & $\%$ of cost & Useful Life Years & Annual Cost $(€)$ & $\%$ of cost \\
\hline Galvanized frame and kit & 5,600 & 31.2 & 20 & 280 & 16.8 \\
\hline Base locking rail & 3,720 & 20.7 & 20 & 186 & 11.1 \\
\hline Polyethylene cover (180 m) & 726 & 4.0 & 2 & 363 & 21.8 \\
\hline Ground cover (375 m) & 160 & 0.9 & 10 & 16 & 1.0 \\
\hline Plastic container (1,344 each) & 2,840 & 15.8 & 10 & 284 & 17.0 \\
\hline Perlite $\left(22 \mathrm{~m}^{3}\right)$ & 420 & 2.3 & 5 & 84 & 5.0 \\
\hline Zeolite $(8,120 \mathrm{~kg})$ & 360 & 2.0 & 5 & 72 & 4.3 \\
\hline Roof sprinkler & 200 & 1.1 & 20 & 10 & 0.6 \\
\hline Water pipe (PVC) (125 m) & 150 & 0.8 & 15 & 10 & 0.6 \\
\hline Water pipe (for drainage) (200 m) & 30 & 0.2 & 15 & 2 & 0.1 \\
\hline Plastic filter & 50 & 0.3 & 10 & 5 & 0.3 \\
\hline Metal filter & 30 & 0.2 & 10 & 3 & 0.2 \\
\hline Stopper & 10 & 0.1 & 5 & 2 & 0.1 \\
\hline Elbow (PVC) & 60 & 0.3 & 15 & 4 & 0.2 \\
\hline Valve & 45 & 0.2 & 15 & 3 & 0.2 \\
\hline Nipple & 10 & 0.1 & 10 & 1 & 0.1 \\
\hline Joint & 10 & 0.1 & 10 & 1 & 0.1 \\
\hline Pressure regulator & 40 & 0.2 & 10 & 4 & 0.2 \\
\hline Adapter & 30 & 0.2 & 10 & 3 & 0.2 \\
\hline Water counter & 410 & 2.3 & 10 & 41 & 2.5 \\
\hline Manometer & 20 & 0.1 & 10 & 2 & 0.1 \\
\hline Drainage tank & 120 & 0.7 & 20 & 6 & 0.4 \\
\hline Buoy & 10 & 0.1 & 10 & 1 & 0.1 \\
\hline $\mathrm{pH}$ meter & 230 & 1.3 & 10 & 23 & 1.4 \\
\hline Electrical Conductivity (EC) meter & 210 & 1.2 & 10 & 21 & 1.2 \\
\hline Timer & 140 & 0.8 & 10 & 14 & 0.8 \\
\hline Water pump $\left(8 \mathrm{~m}^{3} \mathrm{~h}^{-1}\right)$ & 30 & 0.2 & 15 & 2 & 0.1 \\
\hline Site preparation and ground gravel & 480 & 2.7 & $(*)$ & 48 & 2.9 \\
\hline Assembly and installation & 1,770 & 9.9 & $(*)$ & 177 & 10.6 \\
\hline Total $(€)$ & 17,911 & 100.0 & - & 1,668 & 100.0 \\
\hline Total $\left(€ \mathrm{~m}^{-2}\right)$ & 17.91 & - & - & 1.67 & - \\
\hline
\end{tabular}

*Calculated over 10 years (Hickman \& Klonsky, 1993; Estes \& Peet, 1999).

cost between $€ 37 \mathrm{~m}^{-2}$ and $€ 110 \mathrm{~m}^{-2}$ (Greer \& Diver, 2000). In Mississippi, USA, it was estimated that a capital of $€ 65 \mathrm{~m}^{-2}$ was needed for a Quonset-type greenhouse $\left(214 \mathrm{~m}^{2}\right)$ for tomato production (Hood \& Snyder, 1999). In North Carolina, USA, initial investment costs to construct a $214 \mathrm{~m}^{2}$ greenhouse was estimated to be $€ 78 \mathrm{~m}^{-2}$ (Estes \& Peet, 1999). In Virginia, USA, the cost of constructing a pipe-frame greenhouse with heating-ventilating equipment was $€$ $23 \mathrm{~m}^{-2}$ (O’Dell, 1995).

Table 3 focuses on variable costs associated with the production of cucumbers. Total variable costs for growing cucumber were determined as $€ 1,358$ ( $€$ $1.36 \mathrm{~m}^{-2}$ ). Labor cost was $25.4 \%$ of total variable cost.
In addition, fertilizers (ammonium nitrate, nitric acid etc.), pesticides and seedling costs were $22.1 \%, 21.1 \%$ and $15.8 \%$ of total variable costs, respectively. Variable costs were determined as $€ 32.04 \mathrm{~m}^{-2}$ for the production of cucumber crop in a $1,860 \mathrm{~m}^{2}$ greenhouse for California, USA (Hickman \& Klonsky, 1993). On the other hand, variable costs for production of organic cucumber were determined to be $€ 0.71 \mathrm{~m}^{-2}$ in New Jersey, USA (Rutgers Cooperative Extension, 1996).

Total costs of cucumber production were determined to be $€ 3,470$ ( $€ 3.47 \mathrm{~m}^{-2}$ ). Variable and fixed costs were $39.1 \%$ and $60.9 \%$ of the total costs, respectively (Table 4). In this study, cost to produce 1 
Table 3 - Variable costs of soilless cucumber production $\left(1,000 \mathrm{~m}^{2}\right)$.

\begin{tabular}{|c|c|c|}
\hline Operation & Total cost $(€)$ & $\%$ of cost \\
\hline Container preparation and filling (labor) (28 hours) & 16 & 1.18 \\
\hline Calcium nitrate $(169 \mathrm{~kg})$ & 30 & 2.21 \\
\hline Ammonium nitrate $(21 \mathrm{~kg})$ & 2 & 0.1 \\
\hline Potassium nitrate $(311 \mathrm{~kg})$ & 76 & 5.6 \\
\hline Magnesium sulfate $(172 \mathrm{~kg})$ & 35 & 2.6 \\
\hline Chelated iron $(9 \mathrm{~kg})$ & 105 & 7.7 \\
\hline Phosphoric acid (35 liter) & 13 & 1.0 \\
\hline Nitric acid (154 liter) & 28 & 2.1 \\
\hline Manganese sulfate $(1.8 \mathrm{~kg})$ & 4 & 0.3 \\
\hline Copper sulfate $(0.3 \mathrm{~kg})$ & 2 & 0.1 \\
\hline Zinc sulfate $(1.7 \mathrm{~kg})$ & 1 & 0.1 \\
\hline Boric acid $(1 \mathrm{~kg})$ & 2 & 0.1 \\
\hline Ammonium molybdate $(0.04 \mathrm{~kg})$ & 3 & 0.2 \\
\hline Fertilization (labor) (42 hours) & 24 & 1.8 \\
\hline Planting (labor) (40 hours) & 19 & 1.4 \\
\hline Seedlings $(2,688$ each $)$ & 215 & 15.8 \\
\hline Irrigation (labor) (78 hours) & 48 & 3.6 \\
\hline Electricity $(216 \mathrm{kw} / \mathrm{h})$ & 145 & 10.7 \\
\hline Pruning and training (labor) (86 hours) & 52 & 3.8 \\
\hline Fungicide and insecticide application (labor) (42 hours) & 24 & 1.8 \\
\hline Fungicides and insecticides & 286 & 21.1 \\
\hline Yellow traps $(10 \mathrm{~kg})$ & 8 & 0.6 \\
\hline Glue (for traps) (4 tube) & 2 & 0.1 \\
\hline Harvest (labor) (224 hours) & 128 & 9.4 \\
\hline Wrapping (labor) (56 hours) & 32 & 2.4 \\
\hline Plastic wrapping (16 kg) & 19 & 1.4 \\
\hline Transport & 39 & 2.9 \\
\hline Total variable costs $(€)$ & 1,358 & 100.0 \\
\hline Total variable costs $\left(€ \mathrm{~m}^{-2}\right)$ & 1.36 & - \\
\hline
\end{tabular}

$\mathrm{kg}$ of cucumber was calculated as $€ 0.11$ ( $€ 3,470 /$ $31,263 \mathrm{~kg}=€ 0.11$ ). However, production cost of 1 $\mathrm{kg}$ cucumber was estimated as $€ 0.14$ in a $1,035 \mathrm{~m}^{2}$ greenhouse located in the region which experiment was realized (Engindeniz, 2004). On the other hand, it was reported that the cost of production of $1 \mathrm{~kg}$ of cucumber was determined to be $€ 1.52$ in a $1,860 \mathrm{~m}^{2}$ greenhouse in California, USA (Hickman \& Klonsky, 1993).

\section{Marketing and Pricing}

Harvested greenhouse cucumbers were marketed at local markets and the wholesale market of Izmir after packing in plastic bags. The basic determinants of the profitable greenhouse production are the economical rather than the ecological factors. Domestic market dynamics take first place among these factors. The existence of a large domestic market in Turkey is the most important factor in terms of supporting development of greenhouse production. Particularly large population, with relatively high growth, in addition to increases per capita income creates demand for greenhouse products.

Domestic market was relatively more important, particularly during the first days of marketing of greenhouse products (Yilmaz et al., 2005). Looking at the developments of prices in both greenhouse and open area production, price difference between two production systems decrease gradually as time passes. This situation indicates that domestic market has reached saturation in terms of meeting domestic demand. Hence production increases can cause sharp domestic price decreases and as a result many producers can be affected negatively from this development. At this point, export of the greenhouse product appears as an 
Table 4 - Total costs of soilless cucumber production $\left(1,000 \mathrm{~m}^{2}\right)$.

\begin{tabular}{|c|c|c|c|}
\hline \multicolumn{2}{|l|}{ Item } & Total costs $(€)$ & $\%$ of cost \\
\hline \multicolumn{2}{|l|}{ Variable costs (I) } & 1,358 & 39.1 \\
\hline \multirow{6}{*}{ Fixed costs (II) } & Interest on total initial investment costs & 1,075 & 31.0 \\
\hline & Annual initial investment costs & 834 & 24.1 \\
\hline & Interest on total variable costs & 81 & 2.3 \\
\hline & Administrative costs & 41 & 1.2 \\
\hline & Land rent & 81 & 2.3 \\
\hline & Total & 2,112 & 60.9 \\
\hline \multicolumn{2}{|c|}{ Total costs $(\mathrm{I}+\mathrm{II})(€)$} & 3,470 & 100.0 \\
\hline \multicolumn{2}{|c|}{ Total costs $\left(€ \mathrm{~m}^{-2}\right)$} & 3.47 & - \\
\hline
\end{tabular}

important factor in terms of preventing domestic price decreases. When the exports low, domestic prices of greenhouse products decrease very rapidly. In this study, soilless produced cucumbers were sold for an average of $€ 0.17 \mathrm{~kg}^{-1}$. This is the price received by the grower.

\section{Gross Revenue and Net Return}

Total gross revenue obtained from cucumbers was determined as $€ 5,315$ (€5.31 $\mathrm{m}^{-2}$ ) (Table 5). Total costs of cucumber production were determined as $€$ 3,470 . Therefore, total net return was calculated as $€$ 1,845 (Table 6). Net return was calculated as $€ 1.84$ $\mathrm{m}^{-2}$ and $€ 0.06 \mathrm{~kg}^{-1}$ (€1,845/31,263 kg=€0.06). Variable costs and fixed costs had a share of $25.6 \%$ and $39.7 \%$ in gross revenue, respectively, the rest (34.7\%) was net return (Table 6).

\section{Comparative Analysis of Soilless and Soil-based Cucumber Production}

Table 7 was prepared for comparing economic aspects of soilless and soil-based cucumber production. According to results of a survey in the region, it was assumed that average total yield of conventional soilbased cucumber production in a $1,000 \mathrm{~m}^{2}$ greenhouse was $23,000 \mathrm{~kg}$. Further, average variable costs and total costs for soil-based cucumber production in a 1,000 $\mathrm{m}^{2}$ greenhouse were determined as $€ 1,222$ and $€$ 2,662 , respectively. Total net return obtained from soilbased cucumbers was calculated as $€ 1,478$ ( $€ 1.48$ $\mathrm{m}^{-2}$ ).

Variable and fixed costs of soilless production were higher than soil-based production. Although material costs and total costs were higher for soilless culture systems compared to soil-based systems, adjusted cost and operating costs were generally lower and overall crop yield far exceed the soil-based one. But net return of soilless production $\left(€ 1.84 \mathrm{~m}^{-2}\right.$ ) was higher than soilbased production ( $€ 1.48 \mathrm{~m}^{-2}$ ) because its yield and gross revenue are higher. Soilless cucumber production is an economically viable alternative to soil-based cu-
Table 5 - Gross revenue obtained from soilless cucumber $\left(1,000 \mathrm{~m}^{2}\right)$.

\begin{tabular}{lccc}
\hline $\begin{array}{l}\text { Marketable } \\
\text { yield }\end{array}$ & $\begin{array}{c}\text { Average } \\
\text { price }\end{array}$ & $\begin{array}{c}\text { Total gross } \\
\text { revenue }\end{array}$ & $\begin{array}{c}\text { Gross revenue } \\
\mathrm{m}^{-2}\end{array}$ \\
\hline $\mathrm{kg}$ & $€ \mathrm{~kg}^{-1}$ & $-\ldots-\ldots-\ldots$ & $\ldots$ \\
31,263 & 0.17 & 5,315 & 5.31 \\
\hline
\end{tabular}

Table 6 - Net return obtained from soilless cucumbers $(1,000$ $\left.\mathrm{m}^{2}\right)$.

\begin{tabular}{|c|c|c|}
\hline Item & Total & Proportion of revenue \\
\hline & $€$ & $\%$ \\
\hline Total gross revenue (I) & 5,315 & 100.0 \\
\hline Variable costs & 1,358 & 25.6 \\
\hline Fixed costs & 2,112 & 39.7 \\
\hline Total costs (II) & 3,470 & 65.3 \\
\hline Total Net return (I-II) (€) & 1,845 & 34.7 \\
\hline Net return $\left(€ \mathrm{~m}^{-2}\right)$ & 1.84 & - \\
\hline
\end{tabular}

cumber production (Table 7). However, in a study done in Menderes, net return obtained with organic soil-based greenhouse cucumber production varied between $€$ $1.26 \mathrm{~m}^{-2}$ and $€ 2.02 \mathrm{~m}^{-2}$ across all fertilizer treatments (Tüzel et al., 2005). In other studies done in Menderes, net return obtained with conventional soil-based greenhouse cucumber production were calculated to be $€$ $1.59 \mathrm{~m}^{-2}$ (Engindeniz, 2004) and $€ 0.73 \mathrm{~m}^{-2}$ (Engindeniz \& Engindeniz, 2006). In the same province net return obtained from the cucumbers grown in volcanic tuff placed in polyethylene beds by closed substrate culture is reported as $€ 1.85 \mathrm{~m}^{-2}$ (Engindeniz, 2004) and $€ 2.07$ $\mathrm{m}^{-2}$ (Gül et al., 2006).

Some important advantages of soilless greenhouse cucumber production in Menderes were determined in this study. Soilless culture techniques allow a more accurate control of the root environment which offers possibilities for increase of the production and improvement of quality. It has the additional advantages of optimal use of water and nutrients, energy 
Table 7 - The economic comparison of soilless and soil-based cucumber production.

\begin{tabular}{|c|c|c|c|}
\hline \multicolumn{2}{|l|}{ Item } & \multicolumn{2}{|c|}{$\begin{array}{l}\text { Perlite and zeolite-based cucumber production Conventional soil-based cucumber } \\
\left.\text { in horizontal plastic pots (for } 1000 \mathrm{~m}^{2}\right)^{1} \\
\left.\text { production (for } 1000 \mathrm{~m}^{2}\right)^{2}\end{array}$} \\
\hline \multirow{5}{*}{$\begin{array}{l}\text { I. Variable } \\
\text { costs }(€)\end{array}$} & Labor /Operating & 343 & 569 \\
\hline & Material (*) & 831 & 535 \\
\hline & Electricity & 145 & 53 \\
\hline & Transport & 39 & 65 \\
\hline & Total & 1,358 & 1,222 \\
\hline \multirow{6}{*}{$\begin{array}{l}\text { II. Fixed } \\
\text { costs }(€)\end{array}$} & $\begin{array}{l}\text { Interest on total initial } \\
\text { investment costs }(12 \%)\end{array}$ & 1,075 & 641 \\
\hline & Annual initial investment costs & 834 & 601 \\
\hline & Interest on total variable costs & 81 & 73 \\
\hline & Administrative costs (3\%) & 41 & 37 \\
\hline & Land rent & 81 & 88 \\
\hline & Total & 2,112 & 1,440 \\
\hline \multicolumn{2}{|c|}{ Total Costs (I+II) } & 3,470 & 2,662 \\
\hline \multicolumn{2}{|c|}{ Total yield (kg) } & 31,263 & 23,000 \\
\hline \multicolumn{2}{|c|}{ Adjusted cost $\left(\mathrm{kg}^{-1}\right)$} & 0.11 & 0.12 \\
\hline \multicolumn{2}{|c|}{ Average price of cucumbers $\left(€ \mathrm{~kg}^{-1}\right)$} & 0.17 & 0.18 \\
\hline \multicolumn{2}{|c|}{ Total gross revenue $(€)$} & 5,315 & 4,140 \\
\hline \multicolumn{2}{|c|}{ Total net return $(€)$} & 1,845 & 1,478 \\
\hline \multicolumn{2}{|c|}{ Net return $\left(€ \mathrm{~m}^{-2}\right)$} & 1.84 & 1.48 \\
\hline
\end{tabular}

*Seedling, chemicals, wrapping etc. ${ }^{1}$ The results of current study. ${ }^{2}$ The results derived from survey with the growers in the region.

saving while soil disinfection is no longer necessary. On the other hand, investments have to be done in construction and maintenance of the systems. Introduction of soilles systems involves an increase of inputs for the construction and maintenance, compared to the cultivation in soil. The degree of increase of inputs depends on the soilless system used and also the degree of perfection of control measures used by the particular system adopted, i.e., the initial cost for establishing a soilless system is higher compared to soil-based system, but the annual running cost is lower with the soilles system. Further to the above the cost of the greenhouse structure, the cost of the greenhouse environmental management devices and controls, which are important for a successful soilless culture should be taken into consideration (Olympios, 1999).

To succeed with the soilless culture methods, one must have or to be able to learn and have some knowledge of how to grow the crop, plant physiology, elementary chemistry, familiarity with the control systems, etc. Soilless culture is not an easy operation. Furthermore, scientific and technical support from the research workers, extension services and private enterprises dealing with all relevant materials and accessories for soilless culture, is important. Growing crops in restricted volume requires a higher, standard of management. Successful commercial soilless cultures are demanding good management and skilled staff. Therefore, the person in command must have a very wide range of skills, i.e. able to prepare and adjust the nutrient solutions, set and control electronic equipment, to have knowledge of plant physiology, to recognize and be able to control plant diseases.

Turkish growers started to use soilless culture, but they prefer open substrate culture since it is similar to conventional culture in terms of water and nutrients application. Transition to closed systems from open systems is required to maintain the sustainability of greenhouse production. Using closed systems will result in a reduction of the amount of waste material, less pollution of ground and surface water, a more efficient use of water and fertilizers and lower costs because of the savings. Closed substrate culture can be used in greenhouse production without any reduction in income of the farmers compared to traditional way. As an added benefit it will also eliminate emissions of fertilizers and pesticides to the environment that is being possible in conventional soil-based growing.

Closed substrate culture is more efficient with the use of water and fertilizers, and cause less damage to the environment. The main advantage provided by closed substrate culture is the restriction of surface and ground water pollution through greenhouse effluents, which are rich in nitrates and phosphates. Moreover, recycling the excess nutrient solution, which runs 
off after each watering application, results in considerable fertilizer savings. The disadvantage of closed substrate culture is the risk of a rapid dispersal of soilborne pathogens by the recirculating nutrient solution. Substrate culture is now the unique technique at Turkish farmers' level and growers prefer to use open system (Tüzel \& Gül, 1999). However,, transition to closed system should be encouraged to maintain sustainability of these techniques. During adaptation stage, the growers should be informed both on technical and economic aspects of the technique.

\section{ACKNOWLEDGEMENTS}

This research was supported by TUBITAK-Scientific and Technical Research Council of Turkey (Contract No: TARP 2580-2). Gratitude is expressed to grower and other individuals who provided assistance.

\section{REFERENCES}

AL-ABDULKADOR, A. Economic feasibility of greenhouse vegetable production in Oklahoma. Stillwater: Oklahoma State University, 1992. p.139. (M.S. Thesis).

BÖHME, M. Influence of closed systems on the development of cucumber. ISOSC Proceedings, v.1, p.75, 1996.

BURRAGE, S.W. The nutrient film technique (NFT) for crop production in the mediterranean region. Acta Horticulturae, v.491, p.301-306, 1999.

CANATAR, E. Investigations on the effects of open and closed systems on yield, water and nutrient consumption of the cucumber plants grown by soilless culture (in Turkish). Ege University, 1997. p. 51. (M.S. Thesis).

CHAUDHARY, G.N. The economics of production and marketing of greenhouse crops in Alberta. Alberta: Agriculture, Food and Rural Development, 2001. p.42.

ENGINDENIZ, S. The economic analysis of growing greenhouse cucumber with soilless culture system: the case of Turkey. Journal of Sustainable Agriculture, v.23, p.5-19, 2004.

ENGINDENIZ, S.; TÜZEL, Y. The economic analysis of organic greenhouse tomato production: a case study for Turkey. Agro Food Industry Hi-Tech, v.13, p.26-30, 2002.

ENGINDENIZ, S.; TÜZEL, Y. Economic analysis of organic greenhouse lettuce production in Turkey. Scientia Agricola, v.63, p.285-290, 2006.

ENGINDENIZ, S.; ENGINDENIZ, D. Economic analysis of pesticide use on greenhouse cucumber growing: a case study for Turkey. Journal of Plant Diseases and Protection v.113, p.193-198, 2006.

ESTES, E.A.; PEET, M. The bottom line in greenhouse tomato production. Raleigh: North Carolina State University, 1999. (Report, 18).

GREER, L.; DIVER, S. Organic greenhouse vegetable production: horticulture production guide. Fayetteville: Appropriate Technology Transfer for Rural Areas, 2000. p.31.

GÜL, A.; TÜZEL, I.H.; TUNCAY, O.; ELTEZ, R.Z.; ZENCIRKIRAN, E. Soilless culture of cucumber in glasshouses. I. A comparison of open and closed systems on growth, yield and quality. Acta Horticulturae, v.491, p.389-393, 1999.

GÜL, A.; TÜZEL, Y.; TÜZEL, I.H.; ELTEZ, R.Z.; MERIC, M.K.; AKAT, O.; DEMIRELLI, A. Researches on developing soilless culture systems suitable for Turkish greenhouse conditions. Izmir: Ege University Scientific Research Projects, 2001. p.73. (Project No. 98/BIL/023).
GÜL, A.; ENGINDENIZ, S.; ELTEZ, R.Z.; AYKUT, N.; GÜLCIN, $\mathrm{H}$. Adaptation of closed substrate culture by small-scale farmers. Acta Horticulturae, v.729, p.261-266, 2006.

GÜL, A.; ENGINDENIZ, S.; AYKUT, N. Can closed substrate culture be an alternative for small-scale farmers?. Acta Horticulturae, v.747, p.83-89, 2007.

HICKMAN, G.W.; KLONSKY, K. Greenhouse cucumbers-bag culture: cost of production and equipment in San Joaquin Valley. Stockton: University of California, 1993. p.4.

HOOD, K.; SNYDER, R. Budget for greenhouse tomatoes. Jackson: Mississippi State University, 1999. p.6.

KAPTAN, M.A. Effects of different nitrogen doses on yield and some quality properties of cucumber cultivation in soilless culture. Aydin: Adnan Menderes University, 2006. p.106. (M.S. Thesis).

KIRAL, T., KASNAKOGLU, H., TATLIDIL, F., FIDAN, H., GÜNDOGMUS, E. Database guide and income and cost calculation methodology for agricultural products. Ankara: Agricultural Economics Research Institute, 1999. p.133. (Publication, 37).

LAZOL, I. General accounting. Bursa: Publications of Ekin, 2007. p.452.

MÜLAYIM, Z. G. Agricultural valuation and expertise, 2nd ed. Ankara: Publications of Yetkin, 2001. p.367.

O'DELL, C. Update on production costs/expected returns budget for greenhouse. Blacksburg: Virginia State University, Department of Horticulture, 1995. p.5.

OLYMPIOS, C.M. Overview of soilless culture: advantages, constraints and perspectives for its use in Mediterranean countries. Cahiers Options Méditerranéennes, v.31, p.307-324, 1999.

OS, E.A. van; RUIJS, M.N.A.; WEEL, P.A. van. Closed business systems for less pollution from greenhouses. Acta Horticulturae, v.294, p.49-57, 1991.

OS, E.A.van. New developments in recirculation systems and disinfection methods for greenhouse crops. In: WORKSHOP ON AGRICULTURAL STRUCTURES AND ACESYS (AUTOMATION, CULTURE, ENVIRONMENT AND SYSTEMS), Ibaraki, 2000. Proceedings. Tsukuba, 2000. p.8191.

ÖZGÜR, M. A Research on the production of cucumber (Cucumis sativus L.) in the media of perlite and volcanic tufa under the controlled conditions. Bursa: Uludag University, 1991. p.64, (PhD Thesis).

ÖZTAN, F. Possibilities of using of organic manure in cucumber production in different substrates. Izmir: Ege University, 2002. p.155, (M.S. Thesis).

PAPADOPOULOS, A.P. Growing greenhouse seedless cucumbers in soil and soilless media. Ottawa: Agriculture and Agri-Food Canada, 1994. p.126.

PENSON, J.B.; CAPPS, O.; ROSSON, C.P. Introduction to agricultural economics. 3 ed. Upper Saddle River: Prentice Hall, Third Edition, 2002. p.572.

RUTGERS COOPERATIVE EXTENSION. Cost of production for cucumber. New Brunswick: Agricultural Experiment Station, 1996. p.7.

SARACOGLU, A. Investigations on the effects of different nitrogen and potassium nutrition rates on plant growth, yield and fruit quality of cucumbers grown by soilless culture. Izmir: Ege University, 1997. p.51. (M.S. Thesis).

TOGNONI, F.; PARDOSSI, A. Soilless culture for greenhouse crops in the Mediterranean countries. In: WORKSHOP ON METHYL BROMIDE ALTERNATIVES FOR NORTH AFRICAN AND SOUTHERN EUROPEAN COUNTRIES, Rome, 1998. Proceedings. Nairobi: UNEP, 2000. p.143-148.

TÜZEL, I.H.; IRGET, M.E.; GÜL, A.; TUNCAY, O.; ELTEZ, R.Z. Soilless culture of cucumber in glasshouses. II. A comparison of open and closed systems on water and nutrient consumption. Acta Horticulturae, v.491, p.395-400, 1999.

TÜZEL, Y.; GÜL, A. Soilless culture in Turkey. In: THEMATIC WORKSHOP FOR SOILLESS CULTURE, Halkidiki, 1999. Proceedings. Halkidiki: [s.n], 1999. p.16. 
TÜZEL, Y.; GÜL, A.; TUNCAY, Ö.; ANAC, D.; MADANLAR, N.; YOLDAS, Z.; GÜMÜS, M.; TÜZEL, I.H., ENGINDENIZ, S. Organic cucumber production in the greenhouse: a case study from Turkey. Renewable Agriculture and Food Systems, v.20, p.206-213, 2005.

TÜZEL, Y.; GÜL, A.; ÖZTEKIN, G.B. Recent developments in protected cultivation in Turkey. In: COORDINATING MEETING OF THE REGIONAL FAO WG ON GREENHOUSE CROP PRODUCTION IN THE SEE COUNTRIES, 2., Antalya, 2008. Proceedings. [s.l.]: [s.n.], 2008. p.75-85.

VERNOOIJ, C.J.M. Reduction of environmental pollution by recirculation of drainwater in substrate cultures. Acta Horticulturae, v.303, p.9-13, 1992.
WILLUMSEN, J. Greenhouse cucumber variaties with and without recirculated nutrient solution. [s.l]: [s.n.], 1995. p.28. (3P-Reppart-Statens-Planteavelsforsog).

YILMAZ, I.; SAYIN, C.; ÖZKAN, B. Turkish greenhouse industry: past, present, and future. New Zealand Journal of Crop and Horticultural Science, v.33, p.233-240, 2005.

Received May 30, 2007

Accepted February 16, 2009 